\title{
The Effect of Four Recipient Strains on Intra-uterine Growth in Mice Birth Weight
}

\author{
Yasunori SASAKI, Kazuaki NONAKA, and Minoru NAKATA \\ Department of Pediatric Dentistry, Faculty of Dentistry, Kyushu University, 3-1-1 \\ Maidashi, Higashi-ku, Fukuoka 812, Japan
}

(Received 22 May 1992/Accepted 25 December 1992)

\begin{abstract}
The embryo transfer technique is a very powerful tool for detecting intra-uterine effects of dams on prenatal growth of embryos. Embryos of DDD strain were transferred to a recipient of the same strain. Litter size, gestation period and birth weight of newbron offspring were measured. To examine the effect of embryo transfer on the prenatal growth of embryos, these results were compared with those of newborn DDD strain of mice that had developed from non-transferred embryos. Embryos of DDD strain were transferred to four strains of recipients (DDD/Qdj, C3H/Qdj, C57BL/Qdj and DBA/1J Sea). Litter size, gestation period and birth weight of newborn offspring were measured. The four strains of recipients were compared to examine the effect of recipient strain on the prenatal growth of the embryos. The results were as follows. 1. There was no gender difference in birth weight of offspring. 2. A negative correlation (partial regression coefficients: $-0.024, \mathrm{P}<0.001$ in the transfer and non-transfer groups, and $-0.058, \mathrm{P}<0.001$, in the four strains of recipients) was observed between litter size and birth weight of newborn offspring, while a positive correlation (partial regression coefficients : $0.068, \mathrm{P}<0.001$ in the transfer and non-transfer groups, and $0.071, \mathrm{P}<0.001$ in the four strains of recipients) was observed between gestation period and birth weight of newborn offspring. 3. Embryo transfer might affect the intra-uterine growth of transferred embryos. 4. The four different strains of recipients might contribute unequally to the prenatal growth of transferred embryos because of their different intra-uterine conditions. After statistically eliminating the effects of both litter size and gestation period, birth weight of newborn offspring that developed from the same DDD/Qdj strain of embryo increased significantly when developed in DDD/Qdj and C3H/Qdj, which had larger body weights than C57BL/Qdj and DBA/ 1J Sea.-KEY WORDS : birth weight, litter size, gestation period, mice embryo transfer, strain effect
\end{abstract}

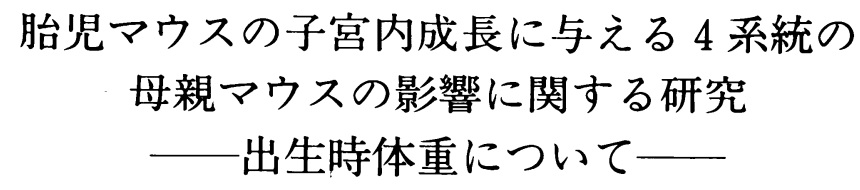

佐々木康成・野中和明・中田稔

九州大学歯学部小児歯科学教室 
ラットの成長に及ほす遗伝要因・母体要因およびその 他の環境要因の相対的影響を調へ，出生後初期の成長 発育における母体要因の重要性を指摘した。この母体 要因としては，大別して出生前母体要因と出生後母体 要因がある。前者としては, 胎児の成長に対する母親 の子宮内環境が, 後者としては新生児に対する育児・ 哺育能力などが考えられる。

この両者を区別する実験方法として, 受精卵移植手 技は極めて有効な手段である。このマウス受精卵移植 法により, 今までにも受精卵の子宮内での生存率や子 宮内成長に及ほす母親マウスの出産回数・年跲および 体重の影響 [12] や子宮内䍗境の影響など $[1,4,5$, 15,16] が調べられてきた。そして, 受精卵移植によ ク生まれな新生児マウスの, 出生時での体重や尾長 に，母親マウスの子宮内璄境が影響していることが明 らかにされた。しかしながら,これらの研究は, 用い たレシピエントマウスの系統数, 匹数が比較的少な く，未だ，移植された受精卵の子宮内成長に及ほすレ シピエント雌マウスの子宮内㻴境の影響が十分に解明 されたとは言い難い。そこで, 本研究では実験規模を 拡大し， 1 系統の近交系マウスの受精卵を，4 系統の 近交系マウスに移植し，胎児マウスの子宮内での成長 が，母親マウ久の系統の違いによって影響を受けるか どうか調へた。また，受精卵移植手技そのものが, 胎 児マウスの子宮内での成長に影響を与えるかどうかに ついても検討した。

\section{材料および方法}

本実験では，Table 1に示したように DDD/Qdj 系 統の 4 週粭の未経産雌マウスを受精卵のドナーとし て,一方 DDD/Qdj, C3H/Qdj, C57BL/Qdj 及び DBA/1J Sea の 4 系統の10週䑪の未経産雌マウスを， 受精卵のレシピエントとした。各マウスはプラスチッ ク製の飼育ケージに入れ，床敷に木屑を用いた。飼料 (MRストック，ノーサン：東京）および水は自由捸 取とした。室温を $25^{\circ} \mathrm{C} \pm 3{ }^{\circ} \mathrm{C}$ に, 湿度を $55 \pm 10 \%$ に維 持し,人工照明を $8: 00$ から $20: 00$ の間に行った。 実験手順：多くの受精卵を効率的に得る為に，4週缽 の DDD 未経産雌マウスを用いて, 過排卵処理を行っ た。即ち，15：00に5i.u.の PMSG（妊馬血清性性腺 刺激ホルモン) とそれに続けて46時間後に5i.u.の hCG（妊婦尿性性腺刺激ホルモン）を腹腔内投与し た。ついで, 1 匹ずつ, 繁殖能力か確認されている20
Table 1. Experimental design for embryo transfer (Mean and standard error)

\begin{tabular}{llcc}
\hline $\begin{array}{l}\text { Strain of } \\
\text { embryo }\end{array}$ & $\begin{array}{l}\text { Strain of } \\
\text { recipient }\end{array}$ & $\begin{array}{l}\text { No. of } \\
\text { recipient }\end{array}$ & $\begin{array}{l}\text { Body weight of } \\
\text { recipient }(\mathrm{g})\end{array}$ \\
\hline & DDD/Qdj & 25 & $26.97 \pm 0.46^{\mathrm{a}}$ \\
DDD/Qdj & C3H/Qdj & 25 & $20.65 \pm 0.46^{\mathrm{b}}$ \\
& C57BL/Qdj & 21 & $19.93 \pm 0.50^{\mathrm{b}}$ \\
& DBA/1J Sea & 27 & $17.43 \pm 0.44^{\mathrm{c}}$ \\
\hline
\end{tabular}

a, b. c : Within the same column, means for recipient strains (DDD, C3H, C57BL, DBA) that have different superscripts in common are significantly different $(\mathrm{P}<0.05)$

週秢前後の DDD 雄マウス 1 匹と同居させた。翌朝, 胵栓の存在によって交配を確かめた。この日を受精卵 の日龄 0 と設定し, hCG 投与 3.5 日後（日羭 3 ) に,ドナー䧳マウスを $\mathrm{CO}_{2}$ 吸入により屠殺し， $5 \%$ $\mathrm{CO}_{2}$ ガスを通した $37^{\circ} \mathrm{C} の$ Whittingham's medium

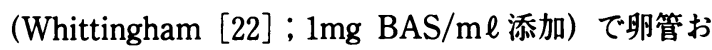
よび子宮内を潅流することにより胚を採取し，このう ち初期胚盤胞のみを集め, Biggers' medium (Biggers [3]；4mg BSA/me 添加）に移した。この初期 胚盤胞を, 必要最小限の Biggers' medium と一緒に マイクロピペット(Wiretrol, フナコシ：東京) 内に

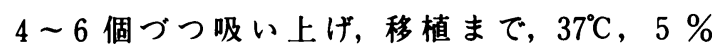
$\mathrm{CO}_{2}, 95 \%$ 空気相の条件下で培養した。一方, レシピ エントとして用いた 4 系統の未経産雌マウスは, ドナ 一とは 1 日遅れのスケジュールで, 精管を切除し不妊 を確認した雄マウスと交配させ, 翌朝, 鍸栓の存在に より交配を確認した。更にこれらのマウスのうち，偽 妊娠 2 日目に胵垢を影徽鏡下で観察し, 性周期が Diesterous stage と判定された雌マウスのみをレシピ エントとして用いた。各レシピエント雌マウスは，エ トレン（大日本製薬：大阪）の吸入麻酔で静止状態に し，背部を切開して子宮角を露出させた。そして左右 の子宮角の中に，あらかじめ用意しておいた受精卵を マイクロピペットで, 各レシピエント毎に 8 ～12個ず つ移植した。移植後12日目（日觝15）から，レシピエ ントの出産の有無を毎日 3 回確認し, 生まれてきた新 生児マウスを移植群とした。出産日における受精卵の 日粭を妊娠期間と定義し, 出産直後にこれら新生児マ ウスの産子数, 妊娠期間および出生時体重を記録し た。また，同時期に10週竛の DDD 雌マウスを，20週 跲前後の DDD 雄マウスと交配させ, 通常の分婏より 生まれてきた新生児マウスを非移植群とし, DDD マ ウスの移植群と同様な項目について測定した。 
Table 2. Birth weight, litter size and gestation period of newborn offspring for four strains of recipients (Mean and standard error)

\begin{tabular}{|c|c|c|c|c|c|}
\hline $\begin{array}{l}\text { Strain of } \\
\text { recipient }\end{array}$ & $\begin{array}{l}\text { No. of } \\
\text { recipient }\end{array}$ & $\begin{array}{l}\text { No. of } \\
\text { offspring }\end{array}$ & Birth weight $(\mathrm{g})$ & $\begin{array}{l}\text { Litter size } \\
\text { (Min-Max) }\end{array}$ & $\begin{array}{l}\text { Gestation period } \\
\text { (Min-Max) }\end{array}$ \\
\hline $\mathrm{DDD} / \mathrm{Qdj}$ & 25 & 74 & $1.62 \pm 0.03^{\mathrm{a}}$ & $\begin{array}{c}3.0 \pm 0.4^{\mathrm{a}} \\
(1-7)\end{array}$ & $\begin{array}{c}20.3 \pm 0.1^{\mathrm{a}} \\
(19-23)\end{array}$ \\
\hline $\mathrm{C} 3 \mathrm{H} / \mathrm{Qdj}$ & 25 & 85 & $1.56 \pm 0.02^{\mathrm{ab}}$ & $\begin{array}{l}3.4 \pm 0.4^{\mathrm{a}} \\
\quad(1-11)\end{array}$ & $\begin{array}{c}19.9 \pm 0.1^{\mathrm{a}} \\
(19-21)\end{array}$ \\
\hline C57BL/Qdj & 21 & 73 & $1.51 \pm 0.03^{b}$ & $\begin{array}{l}3.6 \pm 0.4^{\mathrm{a}} \\
\quad(1-7)\end{array}$ & $\begin{array}{c}20.3 \pm 0.2^{\mathrm{a}} \\
\quad(19-22)\end{array}$ \\
\hline DBA/1J Sea & 27 & 77 & $1.38 \pm 0.03^{\mathrm{c}}$ & $\begin{array}{l}2.9 \pm 0.4^{\mathrm{a}} \\
\quad(1-8)\end{array}$ & $\begin{array}{c}20.0 \pm 0.1^{a} \\
\quad(19-21)\end{array}$ \\
\hline
\end{tabular}

a, b. c : Within the same column, means for recipient strains (DDD, C3H, C57BL, DBA) that have different superscripts are significantly different $(P<0.05)$

統計分析法：新生児マウスの出生時体重に影響を与え る因子として，レシピエントの系統，産子数および妊 娠期間を含んだ数学的モデル式を次のように設定し た。

$\mathrm{Y}_{\mathrm{ij}}=\mu+\mathrm{S}_{1}+\mathrm{a} \quad\left(\mathrm{L}_{\mathrm{ij}}-\overline{\mathrm{L}}_{\mathrm{i}}\right)+\mathrm{b} \quad\left(\mathrm{P}_{\mathrm{ij}}-\overline{\mathrm{P}}_{\mathrm{i}}\right)+\mathrm{e}_{\mathrm{ij}}$

$\mu$ は集団全体における新生児マウスの出生時体重の平 均值, $\mathrm{S}_{1}$ は $\mathrm{i}$ 番目の系統の効果, $\mathrm{L}_{1 \mathrm{j}}$ は $\mathrm{i}$ 番目の系統 の $\mathrm{j}$ 番目の個体における同腹子マウスの匹数である産 子数, $\mathrm{P}_{\mathrm{ij}}$ は $\mathrm{i}$ 番目の系統の $\mathrm{j}$ 番目の個体における妊 娠期間， $\overline{\mathrm{L}}_{1} ， \overline{\mathrm{P}}_{1}$ は，それぞれ $\mathrm{i}$ 番目の系統の産子数お よび妊娠期間の平均値， $\mathrm{a} ， \mathrm{~b}$ は, 産子数と妊娠期間 それぞれに対する偏回帰係数で，これらは産子数の違 いによる効果と妊娠期間の違いによる効果を除外する ために加えたものである。 $\mathrm{e}_{1 \mathrm{j}}$ はランダム効果であ る。この数学的モデル式に基づいて新生児マウスの出 生時体重に関して, 系統の影響の有意性の有無を分散 分析法を用いて検定した。

一方, 受精卵移植手技が胎児マウスの子宮内での成 長に及ほす影響をみるために，同一系統の DDD マウ スを用いて行った実験では, 産子数に関して, 移植群 の方が非移植群より少なく, 産子数の分布が非連続的 であったので，上記モデル式による分散分析は適用し 難い。そこで, 本研究では, 従来から用いられてきた ように $[6,10]$, 出生時体重を独立变数に, 産子数と妊 娠期間を従属变数とした次のような重回帰方程式を適 用して, 産子数と妊娠期間をそれぞれ 3 匹と19日に統 一補正したときの 2 群の出生時体重の推定を行った。 $\hat{\mathrm{Y}}_{\mathrm{ij}}=\mathrm{Y}_{\mathrm{ij}}+\mathrm{a} \quad\left(\mathrm{L}_{\mathrm{ij}}-3\right)+\mathrm{b} \quad\left(\mathrm{P}_{\mathrm{ij}}-19\right)$

ここで, $\hat{\mathrm{Y}}_{1 \mathrm{j}}$ は $\mathrm{i}$ 番目の群の $\mathrm{j}$ 番目の新生児マウスの
出生時体重の予測值, $\mathrm{Y}_{\mathrm{ij}}$ は $\mathrm{i}$ 番目の群の $\mathrm{j}$ 番目の新 生児マウスの実際に測定した出生時体重, $\mathrm{L}_{1 \mathrm{j}}$ と $\mathrm{P}_{1 \mathrm{j}}$ は, $\mathrm{i}$ 番目の群の $\mathrm{j}$ 番目の個体の産子数および妊娠期 間, a, b は, 各群における出生時体重に対する産子 数と妊娠期間のそれぞれの偏回帰係数である。推定さ れた新しい出生時体重について, 移植群と非移植群間 で，それぞれ Student's t-test を用いて比較した。な お, 出生時体重については, 移植群 (雌: $1.49 \mathrm{~g}$, 雄 $1.54 \mathrm{~g}, \mathrm{P}=0.11$ ) と非移植群（雌: $1.49 \mathrm{~g}$, 雄 : $1.53 \mathrm{~g}, \mathrm{P}=0.13)$ とも有意な䧳雄差を認めなかった ので, 雌雄一緒にデータをプールして分析した。全て の統計学的分析は, 九州大学大型計算機センターの SASを用いて行った。

\section{成}

1. 4 系統の母親マウス間での比較; 出産に至った 4 系統の母親マウスの匹数および出生した新生児マウ スの総匹数, 平均出生時体重, 平均産子数および平均 妊娠期間を Table 2にそれぞれ示した。DDD，C3 $\mathrm{H}, \mathrm{C} 57 \mathrm{BL}$ および DBAの 4 系統レシピエントから 産生した新生児マウスの出生時平均体重は, $\mathrm{DDD}>\mathrm{C} 3$ $\mathrm{H}>\mathrm{C} 57 \mathrm{BL}>\mathrm{DBA}$ の順となった。DDD レシピエント から産生した新生児マウスの出生時体重は, C57BL およびDBA レシピエントからのそれより有意に重か った。また， C3H レシピエントから産生した新生児 マウスの出生時体重は, DDD および C57BL からの それと比べて有意差はなかったが, DBA レシピエン トのそれよりも有意に重かった。胎児マウスの子宮内 
Table 3. Least-squares analysis of variance for birth weight of newborn offspring among four strains of recipients

\begin{tabular}{lrrrr}
\hline \multicolumn{1}{l}{$\begin{array}{l}\text { Source of } \\
\text { Variation }\end{array}$} & d.f. & s.s. & m.s. & F-value \\
\hline Strain & 3 & 2.84 & 0.95 & $32.64^{* * *}$ \\
Litter size $^{\text {a }}$ & 1 & 5.45 & 5.45 & $187.82^{* * *}$ \\
Gestation period $^{\mathrm{b}}$ & 1 & 0.45 & 0.45 & $15.34^{* * *}$ \\
Error & 303 & 8.79 & 0.03 & \\
\hline \multirow{*}{***}{$:(\mathrm{P}<0.001)$} & a $:$ Linear regression on the \\
covariate litter size \\
the covariate gestation period
\end{tabular}

Tabal 4. Differences in estimated birth weight of newborn offspring among four strains of recipients (Least-squares mean and standard error)

\begin{tabular}{lcc}
\hline $\begin{array}{c}\text { Strain of } \\
\text { recipient }\end{array}$ & $\begin{array}{l}\text { No. of } \\
\text { offspring }\end{array}$ & $\begin{array}{l}\text { Estimated } \\
\text { birth weight }(\mathrm{g})^{*}\end{array}$ \\
\hline $\mathrm{DDD} / \mathrm{Qdj}$ & 74 & $1.61 \pm 0.02^{\mathrm{a}}$ \\
$\mathrm{C} 3 \mathrm{H} / \mathrm{Qdj}$ & 85 & $1.58 \pm 0.02^{\mathrm{a}}$ \\
$\mathrm{C} 57 \mathrm{BL} / \mathrm{Qdj}$ & 73 & $1.51 \pm 0.02^{\mathrm{b}}$ \\
$\mathrm{DBA} / 1 \mathrm{~J}$ Sea & 77 & $1.35 \pm 0.02^{\mathrm{c}}$ \\
\hline
\end{tabular}

a, b, c : Within the same column, means for recipient strains (DDD, C3H, C57BL, DBA) that have different superscripts are significantly different $1(\mathrm{P}<0.05)$ * : Value after eliminating the effects of litter size and gestation period on birth weight

Table 5. Birth weight, litter size and gestation period of newborn offspring for transfer and non-transfer group (Mean and standard error)

\begin{tabular}{|c|c|c|c|c|c|}
\hline $\begin{array}{l}\text { Group of } \\
\text { dam }\end{array}$ & $\begin{array}{l}\text { No. of } \\
\text { dam }\end{array}$ & $\begin{array}{l}\text { No. of } \\
\text { offspring }\end{array}$ & Birth weight $(\mathrm{g})$ & $\begin{array}{l}\text { Litter size } \\
\text { (Min-Max) }\end{array}$ & $\begin{array}{l}\text { Gestation period } \\
\text { (Min-Max) }\end{array}$ \\
\hline Transfer & 25 & 74 & $1.62 \pm 0.02^{\mathrm{a}}$ & $\begin{array}{l}3.0 \pm 0.5^{\mathrm{a}} \\
\quad(1-7)\end{array}$ & $\begin{array}{c}20.3 \pm 0.1^{\mathrm{a}} \\
\quad(19-23)\end{array}$ \\
\hline Non-transfer & 26 & 149 & $1.50 \pm 0.01^{\mathrm{b}}$ & $\begin{array}{l}6.5 \pm 0.5^{b} \\
\quad(2-12)\end{array}$ & $\begin{array}{c}19.2 \pm 0.1^{\mathrm{b}} \\
(18-20)\end{array}$ \\
\hline
\end{tabular}

\section{成長に 4 系統の母親マウスの系統の違いが影響を与え} ているかどうか, 前述のモデル式に基づいた分散分析 法により検定 (Table 3)。その結果, 系統の効果, お よび産子数と妊娠期間の一次回帰が有意であった。す なわち，産子数が増えると出生時体重は隇少し, 一方 妊娠期間が長くなると出生時体重は增加する傾向にあ ることが認められた。Table 4は産子数と妊娠期間の 影響を除いた出生時体重を各系統別に示したものであ る。 $\mathrm{DDD}, \mathrm{C} 3 \mathrm{H}, \mathrm{C} 57 \mathrm{BL}$ おび $\mathrm{DBA} の 4$ 系統のレ シピエントから産生した新生児マウスの出生時体重 は, $\mathrm{DDD}>\mathrm{C} 3 \mathrm{H}>\mathrm{C} 57 \mathrm{BL}>\mathrm{DBA}$ の順に重かった。DDD および C3HL シピエントから産生した新生児マウス の出生時体重は, C57BLおよび DBAレシピエント からのそれより有意に重かった。また，C57BLレシ ピエントから産生した新生児マウスの出生時体重は, DBA レシピエントのそれよりも有意に重かった。

2. 移植群と非移植群の比較：次に, DDD マウスに おける移植群（受精卵移植群）と非移植群（非受精卵 移植群）において出産に至った両群の母親マウスの匹 数および出生した新生児マウスの総匹数, 平均出生時 体重, 平均産子数および妊娠期間を Table 5 に示し
Table 6. Differences in expected birth weight of newborn offspring between transfer and nontransfer group (Mean and standard error)

\begin{tabular}{lcc}
\hline $\begin{array}{l}\text { Group of } \\
\text { dam }\end{array}$ & $\begin{array}{l}\text { No. of } \\
\text { offspring }\end{array}$ & $\begin{array}{l}\text { Expected } \\
\text { birth weight }(\mathrm{g})^{*}\end{array}$ \\
\hline $\begin{array}{l}\text { Transfer } \\
\text { Non-transfer }\end{array}$ & 74 & $1.55 \pm 0.02^{\mathrm{a}}$ \\
& 149 & $1.62 \pm 0.01^{\mathrm{b}}$ \\
\hline
\end{tabular}

a, b : Within the same column, means for dam groups (Transfer and Non-transfer) that have different superscripts are significantly different $(\mathrm{P}<0.01)$

* : Value adjusted for litter size and gestation period

た。移植群における新生児マウスの出生時体重は, 非 移植群におけるそれよりも有意に重かった（P< $0.001)$ 。また, 産子数 (3.0匹:6.5匹； P<0.001), 妊娠期間 (20.3日：19.2日； $\mathrm{P}<0.001)$ について は，ともに有意な群差が認められた。前項で述べたよ うに, 出生時体重は, 産子数と妊娠期間によって有意 に影響を受ける。そこで，先に述へた重回帰方程式を 用いて, 両群の平均値のうち, 両群に共通した水準と して，産子数を 3 匹に，妊娠期間を19日に統一補正し たときの新生児マウスの出生時体重の予測值を求め 
た。その結果, 移植群の新生児マウスの出生時体重 $(1.55 \mathrm{~g})$ は非移植群の新生児マウスの出生時体重 $(1.62 \mathrm{~g})$ より有意に軽かった $(\mathrm{P}<0.01$, Table $6)$ 。

\section{考宬}

レシピエントマウスとして，10週㱓のマウスを用い たのは, この週哈前後のレシピエント雌マウスの移植 受精卵の生存率・出産率が最も高いという研究報告に 基づいている $[21]$ 。本実験で用いた各 4 系統のレシ ピエントに移植された受精卵から成長した新生児マウ ス，および，正常の交配によりDDD 雌マウスから産 生した新生児マウスの出生時体重については有意な此 雄差を認めなかった。このように新生児マウスの出生 時体重に性差を認めなかった所見は, Pettersら 「14」の報告と一致するものであった。

移植群での新生児マウスの出生時体重が非移植群に 比へてて重かった原因として, 移植群の産子数 (3.0 匹）が非移植群のそれ (6.5匹) の約半分であること や, 妊娠期間に関して, 移植群 (20.3日) が非移植群 (19.2日）よりも 1 日長く母親の子宮内に滞在し, そ の間も成長していたことによるものと推察される。

本実験で各レシピエントに移植した受精卵の個数 （8１2）は, マウスの自然排卵数に近似したもので あった $[4,15]$ 。それにも関わらず, 結果的に移植群 の産子数は, 非移植群のそれよりも有意に少なかっ た。また, マウス受精卵移植を行った Cowly ら [4] は, 自然交配, 分婏により出産した新生児マウスの産 子数の平均值は 8.4 であり, 受精卵移植により産生し

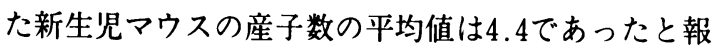
告している。この結果は本実験結果と類似しており, いずれも, 受精卵移植によって産子数が約半数に減少 している。マウス受精卵からは, 着床を成立させるた めの，子宮壁を活性化させる物質が分泌されている

[19]。受精卵を移植する際には, 受精卵とともに, 少量の培養液も子宮内腔に注入される。したがって, 先に述へた子宮活性化物質が培養液で希釈され，その 結果, 着床に何等かの支障をきたした可能性も考えら れる。また, 我々の受精卵移植手技においては, 受精 卵を採取し移植する過程で, 短時間であるにせよ受精 卵を子宮外にさらすため, 受精卵が子宮内と異なる 種々の影響を受けた可能性がある。さらに, 外科的移 植の為に用いたマイクロピペットが, 子宮内膜に損傷
を与えた可能性がある [21]。外科的受精卵移植に関 わるこれらの要因の為, 受精卵の着床やその後の生存 に影響が現れたのであろうと推察している。

本研究においては, このように移植群と非移植群と の間で産子数, 奼娠期間に有意差が認められたので, 両群に共通した水準として，産子数を 3 匹，また好娠 期間を19日に統一補正して新生児マウスの出生時体重 を推定した。その結果, 移植群での出生時体重は非移 植群でのそれより軽くなった。このことは，受精卵移 植手技が，受精卵の着床やその後の生存に影響を及ほ しているだけでなく，胎児マウスの子宮内での成長に も影響を与えた可能性を示唆している。

産子数および妊娠期間の相違による影響を除いたと きの出生時体重におけるレシピエントの系統間の比較 では，有意な系統間差が認められた。過去の研究によ れば，出生前の胎児の成長に及ほす母体要因として， まず, Smith [18] が報告しているように母親の子宮 の大きさが考えられる。本実験における各系統の母親 マウスはそれぞれ系統固有の子宮の大きさを持ってい る。この系統差が子宮内の胎児の成長に影響を及ほし た可能性が十分に考えられる。また，Vorherr [20] は, 胎児一胎盤間の血液潅流およびグルース供給が 重要な影響を及ほしていることを報告した。 Schlager ら [17] は, マウスの血圧には明らかに系 統間で遺伝的な差があると報告しており，胎児一胎盤 間の血液潅流量に系統間差があると考えられる。その ため, 胎児マウスへの酸素や栄養素などの供給がレシ ピエントの系統により異なり, 新生児マウスの出生時 体重がレシピエントの系統によって異なった一因とし て考えられよう $[8]$ 。また, 母親から分泌される黄体 形成ホルモン，エストラダオールやプロゲステロン の分泌量や相对的濃度比が, 受精卵の着床や成長に関 与している $[2,9]$ 。一方で, これらのホルモンの分泌 様式は系統間で有意に異なっている [7]。このこと は, レシピエントの系統間でのホルモンの分泌様式の 違いが, 受精卵の子宮内での成長状態と関連している 可能性があることを示腹している。

今回のマウス受精卵移植実験は, これらの因子につ いて組織学的あるいは生化学的に解析したものではな い。しかしながら，これらの因子が複雑に関連して， 胎児マウスの体重の增加に大きく影響したと考えられ る。そこで, 遺伝的に均一な DDD の受精卵から生ま れた新生児マウスの出生時体重について, 産子数と妊 娠期間の影響を統計学的に除いて検討したところ, 体 
重の重い DDD およびC3H レシピエントの子宮内で 成長した胎児は, 体重の軽いC57BLおよび DBAレ シピエントの子宮内で成長した胎児よりも, 出生時で の体重が重かった。この結果は, 新生児の成長が母体 子宮の要因によって強く影響されていることを示㖫す るものである。

\section{要的}

母親マウスの系統が胎児マウスの子宮内成長に及ほ す影響を調べるために，1 系統のマウス受精卵を 4 系 統の母親マウスに移植し, 生まれてきた新生児マウス の出生時体重, 産子数および妊娠期間について比較検 討した。また, コントロール群として通常の交配, 分 婏により出産した新生児マウスについても，同様の項 目を測定し，実験群と比較し，受精卵移植手技の影響 についても検討した。得られた結果を以下に示した。 1. 新生児マウスの出生時体重に, 性差は認められな かった。2．新生児マウスの出生時体重は, 産子数が 多くなるほど小（偏回帰係数；移植群と非移植群の分 析では, $-0.024, \mathrm{P}<0.001,4$ 系統のレシピエント の分析では， $-0.058, \mathrm{P}<0.001)$ ，妊娠期間が長いほ ど大（偏回帰係数；移植群と非移植群の分析では， 0 . $068, \mathrm{P}<0.001 ， 4$ 系統のレシピエントの分析では, $0.071, \mathrm{P}<0.001 ）$ となる傾向が認められた。3．受 精卵移植手技が, 移植した受精卵の着床やその後の子 宮内成長に影響していることが認められた。4，4 系 統のレシピエント继マウスは，それぞれの子宮内環境 を通して，胎児マウスの子宮内での体重增加に，異な る影響を与えていることが示唆された。すなわち，遗 伝的に均一な DDD/Qdj の受精卵から生まれた新生児 マウスの出生時体重について, 産子数と妊娠期間の影 響を統計学的に除去して検討したところ，体重の重い $\mathrm{DDD} / \mathrm{Qdj}$ および C3H/Qdj レシピエントの子宮内で 成長した胎児は，体重の軽いC57BL/Qdjおよび DBA/1J Sea レシピエントの子宮内で成長した胎児 よりも, 出生時での体重が重かった。

統計学的分析に際し，終始想切な御助言を賜った，九州大学 理学部数学科の柳川克教授に深く御礼申し上げます。なお，本 研究の一部は, 平成 3 年度文部省科学研究費 (一般研究C, 課 題02807188）の補助により行われたものである。

\section{文嗝}

[1] Barkley, M. S. and FitzGerald, R. (1990). Influence of embryonic and maternal genotype on gestational events in the mouse. J. Reprod. Fert., 89, 285-291.

[2] Barkley, M. S., Geschwind, I. I., and Bradford, G. E. (1979). The gestational pattern of estradiol, teststerone and progesterone secretion in selected strains of mice. Biol. Reprod., 20, 733-738.

[3] Biggers, J. D., Whitten, W. K., and Whittingham, D. G. (1971). The culture of mouse embryos in vitro. In Methods in Mammalian Embryolgy, pp88-116, Daniel, J. C. (ed), Freeman, San Fransisco.

[4] Cowley, D. E., Pomp, D., Atchley, W. R., Eisen, E. J., and Howkins-Brown, D. (1989). The impact of maternal uterine genotype on postnatal growth and adult body size in mice. Genetics, 122, 193-203.

[5] Jenkins, A. S. and Anderson, G. B. (1990). Effect on embryo survival of short-term exposure to the uterine environment of two selected lines of mice. Lab. Anim. Sci. , 40, 371-374.

[6 ] Kurisu, K. (1977). The genetic aspects of calcification of molars in mice. Japan. J. Genetics, 52, 41-51.

[7] Maurer, R. R. and Echternkamp, S. E. (1982). Hormonal asynchrony and embryonic development. Theriogenology, 17, 11-22.

[8] Mclaren A. and Michie, D. (1960). Control of prenatal growth in mammals. Nature, 30, 363-365.

[ 9 ] Michael, S. D., Geschwind, I. I., Bradford, G. E., and Stabenfeldt, G. H. (1975). Pregnancy in mice selected for small litter size : Reproductive hormone levels and effect of exogenous hormones. Biol. Re. prod. 12, 400-407.

[10] Nakata, M., Yu, P. L., and Nance, W. E. (1974). Multivariate analysis of craniofacial measurements in twin and family data. Am.J. Phys. Anthrop., 41, 423 -430 .

[11] Nonaka, K., Matsumoto, T., and Nakata, M. (1988). Genetic and environmentel factors in the longitudinal growth of rats : I. Body weight and overall craniofacial size. J. Craniofac. Genet. Dev. Biol., 8, 319-327.

[12] Nonaka, K., Sasada, H., and Nagai, J. (1990). Effects of age and body mass of recipients on survival of transferred embryos in mice. Z. Versuchstierkd, 33, 193-195.

[13] Otani, H., Nonaka, K., and Nakata, M. (1990). Genetic study on the mandibular molar size of rats. $J$. Craniofac. Genet. Dev. Biol., 10, 311-327.

[14] Petters, R. M., Eisen, E. J., Pomp, D., and Lucy, M. C. (1988). Cytoplasmic effects on selection response for increased growth rate in mice. J. Anim. Sci., 66, 287-292.

[15] Pomp, D., Cowley, D. E., Eisen, E. J., Atchley, W. R., and Howkins-Brown, D. (1989). Donor and recipient genotype and heterosis effects on survival and prenatal growth of transferred mouse embryos. $J$. Reprod. Fert., 86, 493-500.

[16] Roth, V. L. and Klein, M. S. (1986). Maternal effects on body size of large insular peromyscus maniculatus evidence from embryo transfer experiments. J. Mamm., 67, 37-45.

[17] Schlager, G. and Weibust, R. S. (1967) . Genetic control of blood pressure in mice. Genetice, 55, 497- 
506.

[18] Smith, D. W. (1977). Basics and nature of growth. In Growth and its disorders, ppl-17, Schaffer, A. J. and Markowitz, M. (eds), W. B. Saunders Company, Philadelphia, London, Toronto.

[19] Spinks, N. R. and O'Neill, C. (1988). Antagonists of embryo-derived platelet-activating factor prevent im plantation of mouse embryos. J. Reprod. Fert., 84,
89-98.

[20] Vorherr, H. (1982). Factors influencing fetal growth. Am. J. Obstet. Gynecol., 142, 577-587.

[21] Wiebold, J. L. and Anderson, G. B. (1986). The effect of recipient age on the success of embryo transfer in mice. Lab. Anim. Sci., 36, 161-163.

[22] Whittingham, D. G. (1971). Culture of Mouse Ova. J Reprod. Fert., Supple. 14, 7-21. 